\title{
Rozwój podmiotów ekonomii społecznej w Polsce ze szczególnym uwzględnieniem regionu opolskiego - uwarunkowania instytucjonalno- organizacyjne
}

\author{
Michał Broniszewski*
}

\begin{abstract}
Streszczenie: Rozwój podmiotów ekonomii społecznej (PES) w województwie opolskim związany jest w głównej mierze z rosnącymi regionalnymi potrzebami społecznymi. Ograniczone środki finansowe w sferze polityki społecznej skutkują brakiem skutecznych i efektywnych rozwiązań w obszarze problemów społecznych i ekonomicznych. Celem artykułu jest ukazanie aktualnego stanu rozwoju PES w województwie opolskim w odniesieniu do perspektywy czasowej 2009-2017. Przedstawiono również zmianę danych ilościowych dotyczących podmiotów ekonomii społecznej w województwie opolskim, w celu ukazania znaczenia tego wskaźnika dla działań publicznych ukierunkowanych na rozwój wsparcia instytucjonalno-organizacyjnego ES. W warstwie teoretycznej wykorzystano analizę literatury przedmiotu, która posłużyła do zbadania uwarunkowań organizacyjnych wspomagających wdrażanie warunków sprzyjających rozwojowi PES w województwie opolskim. W warstwie empirycznej wykorzystano metody analizy danych zastanych (ilościowych) jako metodę badawczą, opierającą się na analizie powstawania nowych PES. Dane te posłużą do lepszego zrozumienia warunków sprzyjających i hamujących rozwój PES w regionie opolskim. Autor wskazuje na niepokojącą tendencję w słabnącej dynamice wzrostu nowych PES.

Słowa kluczowe: ekonomia społeczna, polityka społeczna, przedsiębiorstwa społeczne.
\end{abstract}

\section{Wprowadzenie}

Wokół koncepcji ekonomii społecznej istnieje wiele kontrowersji, odnoszących się m.in. do tego, czy w ekonomii społecznej (ES), wraz z jej własnymi podmiotami, następuje właściwy rozwój instytucjonalno-organizacyjny, czy jest ona skuteczna w przeciwdziałaniu wykluczeniu społecznemu i marginalizacji społecznej (w tym: w województwie opolskim), oraz czy formuła, jaką przyjęła współczesna ES jest ekonomicznie uzasadnioną koncepcją istnienia, czy jedynie pomysłem na szukanie rozwiązań problemów w kwestii polityki społecznej. Próba odpowiedzi na te pytania dokonana zostanie w opar- ciu o literaturę przedmiotu i analizę kierunków rozwoju ekonomii społecznej w regionie opolskim.

Celem artykułu jest poznanie źródeł powstawania koncepcji ES w Polsce, przegląd wojewódzkich programów wsparcia ES w województwie opolskim oraz diagnoza stanu rozwoju PES w regionie opolskim na lata 2009-2017. W artykule wykorzystano

\section{* Michał Broniszewski}

Katedra Studiów Europejskich Wydział Nauk Społecznych Uniwersytet Wrocławski ul. Koszarowa 3, 51-149 Wrocław email: michal.broniszewski@uwr.edu.pl 
przegląd literatury, która posłużyła do zbadania uwarunkowań organizacyjno-instytucjonalnych, wspomagających rozwój podmiotów ekonomii społecznej w województwie opolskim. W ostatniej części artykułu wykorzystano analizę danych zastanych (ilościowych), odnoszących się do stanu istniejących podmiotów ekonomii społecznej, w celu określenia kierunków rozwojowych PES i jego wsparcia instytucjonalno-organizacyjnego w województwie opolskim.

\section{Rozwój koncepcji ekonomii społecznej w Polsce}

Przegląd literatury dotyczącej badań nad ES w Polsce nie jest łatwym zadaniem, z uwagi na złożoność tego pojęcia [Mair, Robinson, Hockerts, 2010, s. 48]. Zalążka powstania ES w Polsce można upatrywać w ruchu społecznym, czy w ruchu spółdzielczym. Ewolucję rozwoju współczesnej koncepcji ekonomii społecznej w Polsce zapoczątkowały głębokie przemiany, co można zauważyć w ideach i koncepcjach rozwijanych współcześnie, w szeroko rozumianej debacie publicznej, jednak jej początek jest głęboko zakorzeniony w historii Polski i łączy się pośrednio z ruchem społecznym. W bogatej polskiej tradycji i historii prekursorami ruchu spółdzielczego byli: Stanisław Staszic, ks. Piotr Wawrzyniak, Edward Abramowski, ks. Wacław Bliziński, Maria Orsetti, Stefan Żeromski, Stanisław Wojciechowski, Teodor Toeplitz, Franciszek Stefczyk, Romuald Mielczarski, Jan Wolski, Stanisław Thugutt [KPRES, 2012, s. 6].

Stanisław Staszic (1755-1826) był oświeceniowym prekursorem spółdzielczości tworząc w 1816 r. na swojej ziemi Towarzystwo Rolnicze Hrubieszowskie [Frączak, 2006, s. 14]. Towarzystwo to powstało na podstawie umowy zawartej z 329 gospodarzami ziemskimi, tworząc tzw. kontrakt Towarzystwa $\mathrm{RH}$, który miał na celu udoskonalenie rolnictwa i przemysłu oraz deklarację wspólnego ratowania się $\mathrm{w}$ nieszczęściach [ibi- dem, s. 15]. Jeżeli chodzi o ziemię, to stanowiła ona własność Towarzystwa tworzącego Wspólnotę mieszkańców dóbr. Ziemia była przekazywana w wieczyste użytkowanie. Poglądy Staszica kształtowane były głównie pod wpływem idei epoki oświeceniowej. W kwestii ekonomii wartością dla Staszica nie było osiąganie maksymalizacji zysku, lecz dbanie o rozwój endogeniczny, rozumiany jako dbanie o tworzenie własnego przemysłu w oparciu o jakość. Kolejnym z innowatorów spółdzielczych był ks. Piotr Wawrzyniak (1849-1910), który 29 maja 1873 r. przekształcił lokalną kasę Oszczędności i Pożyczek w Śremie w Bank Ludowy oparty na nowoczesnych zasadach spółdzielczości, a w 1891 r. został jego patronem. Banki spółdzielcze jako pewien ruch spółdzielczy w okresie zaborów Polski były formą akumulacji pieniądza przez Polaków, wspierały one również rozwój Wielkopolski. Trzecią postacią polskiej historii spółdzielczej był prekursor zarówno ruchu stowarzyszeniowego, jak i ruchu spółdzielczego Edward Abramowski (1868-1918). Przeniósł on na grunt polski ideę pankooperatyzmu, mającą na celu stworzenie „republiki spółdzielczej” poprzez kooperatywy, współpracę, stowarzyszenia, oddolne inicjatywy społeczne [Okraska, 2012, s. 11].

Ks. Wacław Bliziński (1870-1944) był ojcem ekonomicznego wzrostu w gminie Lisków w zaborze rosyjskim. Był pomysłodawcą Spółdzielni Spożywców, do której dołączono piekarnię, mleczarnię, a także Stowarzyszenie Budowlane i Stowarzyszenie Zbożowe. Skupiono się również na aspektach kulturalnych i edukacyjnych. Franciszek Stefczyk (1861-1924) był zaś założycielem wiejskiej spółdzielni oszczędnościowo-pożyczkowej, a także propagatorem „Kas Stefczyka” na wsi galicyjskiej.

Ewolucja rozwoju koncepcji ES w Polsce jest przede wszystkim odpowiedzią na specyficzne zagrożenia i problemy społeczno-gospodarczo-polityczne towarzyszące już od wieków. Koncepcji tej sprzyjały szanse 
rozwojowe, co zapoczątkowało różnego rodzaju inicjatywy, a także miało wpływ na powstanie $\mathrm{i}$ ewolucję organizacji społecznych należących obecnie do sektora ekonomii społecznej. Do kluczowych przykładów wielkich projektów można zaliczyć Społem czy Warszawskq Spółdzielnię Mieszkaniowq. Były one odpowiedzią na problemy społeczne tamtych czasów, stanowiąc wówczas innowacyjne rozwiązania społeczne.

Ewolucja koncepcji ES w Polsce pozwala wyróżnić trzy główne fazy jej rozwoju [Kaźmierczak, 2007, s. 102.]:

- tradycyjna ES (przed II wojną światową),

- stara ES (okres PRL),

- nowa ES (po 1989 r.).

W okresie PRL-u ekonomia społeczna (stara) została zawłaszczona, czego wynikiem było wchłonięcie sektora spółdzielczego do sektora rządowego. Działania te obejmowały konfiskatę majątku spółdzielczego, kontrolę przez organy administracji państwowej, przeniesienie zadań polityki państwa na obszary spółdzielczości, czego przykładem mogło być: budowanie mieszkań (spółdzielnie mieszkaniowe), produkcja artykułów mleczno-spożywczych (spółdzielnie mleczarskie), aktywizacja pracy (spółdzielnie pracy) czy modernizacja rolnictwa (spółdzielnie rolnicze). Negatywną stroną takich działań było przejęcie realizacji zadań polityki państwa oraz uzależnienie się od finansowania z budżetu państwowego [Broniszewski, Goleński, Mesjasz, 2013, s. 146]. Główną różnicę między tradycyjną koncepcją ekonomii społecznej a starą koncepcją ES w Polsce stanowiło odejście od demokratycznych, wewnętrznych struktur społecznych tychże podmiotów na rzecz sterowania centralnego (instytucjonalnego). Jest to jedna z przyczyn dzisiejszego kryzysu spółdzielczości w Polsce. Idea powstała jeszcze przed II wojną światową oparta była na ruchu samoobrony i samopomocy, które nawiązywały do naturalnych ludzkich instynktów: kooperacji i solidarności, a także do istniejących od tysiącleci we wszystkich społeczeństwach instytucji nadających im materialne formy [Okraska, 2012, s. 6]. W okresie socjalizmu w Polsce upaństwowione zostały idea i fundamenty, na których opierała się ekonomia społeczna.

\section{Współczesna ekonomia społeczna w Polsce i Unii Europejskiej}

Współczesna ekonomia społeczna powraca do sektora pozapaństwowego, czyli do pierwotnych korzeni, które ją kształtowały (inicjatywy społeczne). Obecny rozwój ES w Polsce różni się zasadniczo od poprzednich faz rozwojowych (tradycyjnej i starej) - odmienny jest kontekst historyczny i typy problemów, jakie współcześnie występują. Przyczyną powrotu ES do dyskursu publicznego w Polsce i Unii Europejskiej są współczesne problemy bezrobocia, które wiążą się głęboko ze zjawiskiem wykluczenia społecznego, a w konsekwencji z pozostawaniem poza rynkiem pracy oraz wyczerpaniem się możliwości państwa narodowego w skutecznym regulowaniu problemów wywoływanych przez mechanizmy rynkowe. Konieczne staje się tworzenie nowego ładu instytucjonalnego w związku z wyczerpaniem się możliwości starych koncepcji [Kaźmierczak, 2007, s. 102].

Bogaty dorobek historyczny ES w Polsce nie wykształcił dotąd definicji w porządku prawnym, która by określała PES, nadal więc jest kwestią otwartą, jakie podmioty możemy zaliczyć do sektora ekonomii społecznej. Obecnie trwa jednak dyskusja nad kryteriami definicyjnymi sektora podmiotów ekonomii społecznej w Polsce. Jednocześnie uregulowanie instytucjonalne na rzecz rozwoju ES i jego otoczenia funkcjonowania przedsiębiorstw społecznych zostało uwzględnione w Krajowym Programie Rozwoju Ekonomii Społecznej na lata 2014-2020 (KPRES), przyjętym uchwałą nr 164 Rady Ministrów z dnia 12 sierpnia 2014 r. KPRES obejmuje okres 2014-2020 i stanowi rządowy programu roz- 
woju, w rozumieniu ustawy $z$ dnia 6 grudnia 2006 r. o zasadach prowadzenia polityki rozwoju (Dz. U. z 2014 r. poz. 1649). KPRES porządkuje cele i działania związane z ES, których finansowanie na lata 2014-2020 jest równolegle planowane ze środków unijnych, budżetu państwa, w tym funduszy celowych i budżetu jednostek samorządu terytorialnego. Obecnie, według definicji KPRES, ekonomia społeczna to sfera aktywności obywatelskiej, która poprzez działalność ekonomiczną i działalność pożytku publicznego służy: integracji zawodowej i społecznej osób zagrożonych społeczną marginalizacją, tworzeniu miejsc pracy, świadczeniu usług społecznych użyteczności publicznej (na rzecz interesu ogólnego) [KPRES, 2012].

Dokonując przeglądu PES w Polsce można stwierdzić, iż obejmują one następujący katalog form [KPRES, 2012, s. 23]:

- fundacje,

- stowarzyszenia,

- spółdzielnie (spółdzielnie pracy, spółdzielnie inwalidów i spółdzielnie niewidomych),

- spółdzielnie socjalne (Centra Integracji Społecznej, Kluby Integracji Społecznej, Zakłady Aktywności Zawodowej, Towarzystwo Ubezpieczeń Wzajemnych).

Funkcjonowanie podmiotów ekonomii społecznej w Polsce utrudnia brak jednolitej ustawy odnoszącej się do przedsiębiorstw społecznych i wsparcia sektora ekonomii społecznej (w chwili obecnej procedowany jest projekt ustawy o przedsiębiorstwach społecznych i wspieraniu ekonomii społecznej [Projekt, 2015], który może rozwiązać powyższy problem). Niewątpliwie brak jednolitej klasyfikacji PES utrudnia wyodrębnienie właściwych podmiotów, co skutkuje różnymi regulacjami prawnymi w Polsce odnoszącymi się do organizacji pozarządowych, takich jak: stowarzyszenia, fundacje, spółdzielnie czy inne organizacje społeczne, należące obecnie do sektora ekonomii społecznej. Katalog prawny regulujący działalność organizacji pozarządowych zawiera się w:

- ustawie z dnia 6 kwietnia 1984 r. o fundacjach (Dz.U. 1984 nr 21 poz. 97),

- ustawie z dnia 7 kwietnia 1989 r. prawo o stowarzyszeniach (Dz.U. 1989 nr 20 poz. 104),

- $\quad$ ustawie z dnia 27 kwietnia 2006 r. o spółdzielniach socjalnych (Dz.U. 2006 nr 94 poz. 651),

- ustawie z dnia 27 sierpnia 1997 r. o rehabilitacji zawodowej i społecznej oraz zatrudnianiu osób niepełnosprawnych (Dz.U. 1997 nr 123 poz. 776),

- ustawie z dnia 24 kwietnia 2003 r. o działalności pożytku publicznego i o wolontariacie (Dz.U. 2003 nr 96 poz. 873),

- ustawie z dnia 20 kwietnia 2004 r. o promocji zatrudnienia i instytucjach rynku pracy (Dz.U. 2004 nr 99 poz. 1001).

Brak precyzyjnej, jednolitej, powszechnie obowiązującej definicji przedsiębiorstwa społecznego może skutkować nieefektywnym wykorzystaniem środków publicznych (w tym znacznych środków pochodzących ze źródeł unijnych) w nowym okresie programowania 2014-2020. Problem ten zauważono w uzasadnieniu projektu ustawy o przedsiębiorstwach społecznych [Gazeta Podatnika, 2015].

Wzrost zainteresowania się Unii Europejskiej koncepcją ekonomii społecznej spowodowany był w głównej mierze powiększaniem się rozbieżności między oczekiwaniami społecznymi a aktualną sytuacją gospodarczą. Obecnie rozwój ES jest wspierany przez UE poprzez inicjatywę na rzecz przedsiębiorczości społecznej [Komisja Europejska, 2011, s. 8-11]. Argumentem dla podjęcia się tego działania jest sprzyjanie „silnej konkurencyjnej, społecznej gospodarce rynkowej" i włączeniu społecznemu ukierunkowanemu na zatrudnienie. Inicjatywa podejmowana przez Komisję Europejską umieściła gospodarkę i innowacyjność społeczną w obszarze swoich zainteresowań zarówno pod względem spój- 
ności terytorialnej, jak i poszukiwań oryginalnych rozwiązań problemów społecznych. Ponadto ES wpisuje się w strategię Europa 2020, która jako program społeczno-gospodarczy UE dąży do realizacji celów w niej zawartych [Komisja Europejska, 2010, s. 5]:

- wskaźnik zatrudnienia osób w wieku 20-64 lat powinien wynosić 75\%,

- liczbę osób zagrożonych ubóstwem należy zmniejszyć o $20 \mathrm{mln}$.

\section{Wojewódzkie programy ES w województwie opolskim}

Ukazując ekonomię społeczną i jej rozwój w województwie opolskim należy uwzględnić spojrzenie na problemy społeczne tego regionu w kontekście uruchomienia potencjału rozwojowego tkwiącego w samej wewnątrzregionalnej społeczności. Według badań w chwili obecnej ekonomia społeczna jest jednym z najskuteczniejszych sposobów walki z problemami społecznymi [Mair, Robinson, Hockerts, 2010, s. 119].

Ekonomia społeczna ma kluczowe znaczenie dla obszarów zapaści społeczno-gospodarczej, w których wciąż aktualne i przenikające się problemy społeczne blokują rozwój i aktywność [Giza-Poleszczuk, Hausner, 2008, s. 23]. Niewątpliwie głównym problemem społeczno-gospodarczym województwa opolskiego jest bezrobocie, jako znacząca determinanta wpływająca na rozszerzenie się sfery ubóstwa. Brak miejsc pracy został również dostrzeżony przez władze samorządowe woj. opolskiego w ramach „Wojewódzkiej strategii w zakresie polityki społecznej na lata 2016-2025" przygotowanej przez Zarząd Województwa Opolskiego oraz Regionalny Ośrodek Polityki Społecznej w Opolu (ROPS). Bezrobocie jest w niej postrzegane jako czynnik mający wpływ na generowanie ubóstwa, a co za tym idzie na wykluczenie społeczne [Zarząd, 2015, s. 83]. Skutkami bezrobocia są emigracja bezrobotnych poza województwo, tzw. migracja krajowa (do ośrodków metropolitarnych) oraz migracja zagraniczna. Korzyści płynące z rozwoju sektora ES w woj. opolskim zostały dostrzeżone w ramach działań na rzecz rozwoju przedsiębiorczości społecznej w „Wojewódzkim programie pomocy i integracji społecznej na lata 2016-2025". Wskazano w nim, iż działania podejmowane przez podmioty ekonomii społecznej (PES) przyczyniają się do [ROPS, 2015, s. 58]:

- osiągania spójności społecznej,

- sprzyjania wzrostowi zatrudnienia,

- wspierania walki z ubóstwem,

- uczestnictwa w demokracji,

- angażowania obywateli w realne działania na rzecz poprawy ich sytuacji,

- usprawnienia procesów zarządzania,

- zapewnienia stabilnego rozwoju lokalnego rynku pracy, a wraz z nim - dobrobytu całej społeczności.

Zdaniem Opolskiego Urzędu Wojewódzkiego skutecznym działaniem ES jest pobudzanie społeczeństwa lokalnego do powrotu na otwarty rynek pracy poprzez zachęcanie do większej aktywności i przedsiębiorczości społecznej. Przeciwdziałanie ubóstwu i wykluczeniu społecznemu zawarte zostało w założeniach „Wojewódzkiej Strategii w Zakresie Polityki Społecznej na lata 20162025" poprzez [Zarząd, 2015, s. 14]:

- rozwój usług i instytucji reintegracji społecznozawodowej,

- wsparcie sektora ekonomii społecznej,

- rozwój partnerstwa i otoczenia,

- rozwój systemu badań i informacji o sektorze ES.

Rozwój ekonomii społecznej jest nieodzowną determinantą rozwoju endogenicznego, gdyż bazuje na własnych regionalnych zasobach. Cechą właściwą dla PES jest aktywizacja osób wykluczonych społecznie i pobudzanie rozwoju przy niskich nakładach zasobów endogenicznych. Każdy region ze względu na swoją specyfikę ma odmienną sytuację społeczno-gospodarczą, co skutkować może odmiennością uwarunkowań 
rozwoju. System wsparcia ES jest odmienny w każdym z regionów i może posiadać różne cele rozwojowe systemu wsparcia. W województwie opolskim cele strategiczne są zawarte w „Wojewódzkim programie pomocy i integracji społecznej na lata 2016-2025" i są zgodne z Opolskim Programem Ekonomii Społecznej. Ten ostatni dokument wskazuje szereg działań, które powinny być realizowane na rzecz rozwoju opolskiego systemu wsparcia sektora ES. Po pierwsze, ma być to realizowane poprzez zwiększenie umiejętności kadr do prowadzenia profesjonalnej pracy socjalnej z rodziną i dzieckiem, z osobami zagrożonymi wykluczeniem społecznym oraz wykluczonymi w zakresie ich aktywizacji społeczno-zawodowej. Po drugie, doskonalone mają być umiejętności metodyczne oraz społeczne kadry pomocy i integracji społecznej. Po trzecie, stworzony ma zostać kompleksowy system kształcenia kadry pomocy i integracji społecznej w regionie. Podejście to wydaje się zasadne w kontekście aktualnych problemów województwa opolskiego, a konkretnie bezrobocia i starzejącego się społeczeństwa [ROPS, 2016, s. 27].

Ważna staje się w tym momencie kondycja sektora ES w województwie opolskim i dalszy rozwój sektora ES na danym obszarze, a świadczyć o tym może m.in. liczba podmiotów należących do sektora ES.

W województwie opolskim według danych REGON z 2013 r. zarejestrowanych było około 3.167 jednostek spełniających kryteria organizacji pozarządowych, na 10 tys. mieszkańców przypadało więc 31,5 organizacji. Województwo opolskie pod tym względem uplasowało się na 13 miejscu w kraju. Na rysunku 1 przedstawiono dane ilościowe: widoczne są zmiany w liczbie organizacji pozarządowych w województwie opolskim w latach 2009-2015.

\section{Rysunek 1. Zmiany w liczbie organizacji pozarządowych w latach 2009-2015 ogółem dla województwa opolskiego}

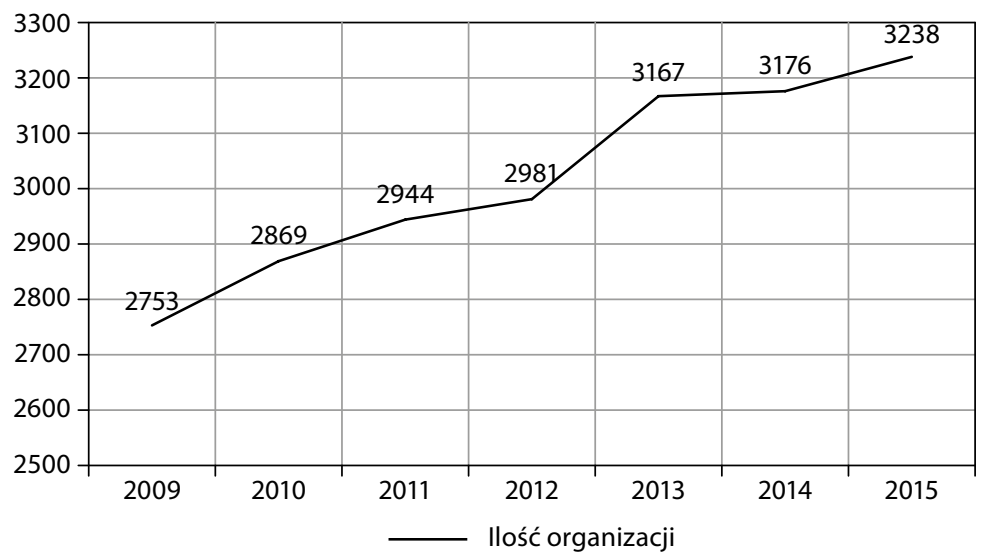

Źródło: opracowanie własne na podstawie bazy danych GUS.

Według danych Krajowego Rejestru Sądowego (KRS) - stan na 24 kwietnia 2017 r., w województwie opolskim funkcjonowało
3.509 organizacji pozarządowych, w stosunku do 131.176 jednostek w całej Polsce (tabela 1). 
Tabela 1. Liczba podmiotów zawartych w bazie KRS, spełniających kryteria organizacji pozarządowych, w podziale na województwa (stan na dzień 24 kwietnia 2017 r.)

\begin{tabular}{|c|c|}
\hline 1. dolnośląskie & 10754 \\
\hline 2. kujawsko-pomorskie & 6493 \\
\hline 3. lubelskie & 7558 \\
\hline 4. lubuskie & 3626 \\
\hline 5. łódzkie & 7610 \\
\hline 6. małopolskie & 11899 \\
\hline 7. mazowieckie & 21928 \\
\hline 8. opolskie & 3509 \\
\hline 9. podkarpackie & 6992 \\
\hline 10. podlaskie & 3858 \\
\hline 11. pomorskie & 7854 \\
\hline 12. śląskie & 12348 \\
\hline 13. świętokrzyskie & 4089 \\
\hline 14. warmińsko-mazurskie & 5236 \\
\hline 15. wielkopolskie & 12146 \\
\hline 16. zachodniopomorskie & 5276 \\
\hline Razem: & 131176 \\
\hline
\end{tabular}

Źródło: opracowanie własne na podstawie bazy danych KRS.

W długookresowej perspektywie można zauważyć powolny, lecz systematyczny wzrost liczby organizacji pozarządowych w województwie opolskim (liczony latami). Natomiast w skali całego kraju województwo opolskie plasuje się na ostatnim miejscu pod względem istniejącej liczby organizacji pozarządowych w KRS-ie. Stanowi to obecnie zagrożenie rozwojowe dla podmiotów ekonomii społecznej. Diagnozując stan (liczbę) organizacji pozarządowych w województwie opolskim ze względu na realizację celów społecznych, można wyodrębnić następujące obszary ich działalności [ROPS, 2016, s. 36]:

- poprawa jakości kształcenia oraz dostosowanie oferty edukacyjnej do potrzeb rynku pracy,

- wspieranie zatrudnienia i samozatrudnienia,

- przeciwdziałanie wykluczeniu społecznemu i ubóstwu,
- rozwój usług opiekuńczych i wychowawczych.

Dla przeciwwagi warto również wymienić bariery hamujące rozwój PES w województwie opolskim. Zaliczyć do nich można [Kwiatkowska i inni, 2011, s. 15]:

- nieliczne i słabe organizacje (pod względem kadrowym i finansowym), co powoduje brak stabilizacji oraz niemożność realizacji celów społecznych,

- niewystarczającą współpracę administracji publicznej z trzecim sektorem, co skutkuje słabą realizacją zadań publicznych z udziałem podmiotów ekonomii społecznej,

- brak zaufania publicznego do inicjatyw podejmowanych przez podmioty ekonomii społecznej oraz brak zaangażowania,

- młody i słabo rozwinięty nurt współczesnej ES, co przyczynia się do niewłaściwych proporcji między realizacją celów 
społecznych a efektywnością gospodarczą.

Jeżeli popatrzymy na instytucjonalno-organizacyjny charakter wsparcia podmiotów ekonomii społecznej w Polsce, ze szczególnym uwzględnieniem województwa opolskiego, to według M. Klimowicz należy wspomnieć o znaczeniu środków unijnych $\mathrm{i}$ „w tym kontekście nie bez znaczenia jest fakt, że rozwój sektora ekonomii społecznej jest obecnie jednym z najważniejszych obszarów wsparcia polityki regionalnej Unii Europejskiej" [Klimowicz, 2008, s. 124].

\section{Podsumowanie}

Rozwój ekonomii społecznej w województwie opolskim wymaga podejścia horyzontalnego na rzecz trwałości i ciągłości realizacji celów społecznych w układzie społeczno-gospodarczym. Rozwiązania instytucjonalno-organizacyjne wspierające rozwój wymagają przede wszystkim stworzenia

\section{Literatura}

Baza danych Krajowego Rejestru Sądowego (KRS), https://ems.ms.gov.pl/krs/wyszukiwaniepodmiotu (dostęp: 24.04.2017).

Baza danych stowarzyszenia KLON/JAWOR, http://www.mojapolis.pl/web/guest;jsessioni$d=277 B 02 A B 20 C A 63 A 1 E F B 851 E 75 E 6823 A 3$ (dostęp: 24.04.2017).

Broniszewski M., Goleński W., Mesjasz K. (2013). "Trzy formy kapitału w podmiotach ekonomii społecznej województwa opolskiego", (w:) A. Zagórowska (red.), Problemy Ślaska ze szczególnym uwzględnieniem województwa opolskiego wyzwaniem dla ekonomii społecznej (s. 140-148). Opole: ROPS w Opolu.

Frączak P. (2006). Szkic do historii ekonomii społecznej w Polsce. Warszawa: FRSO.

Gazeta Podatnika (2015). „Przedsiębiorstwa społeczne doczekają się własnej ustawy", Gazeta Podatnika, nr 67 (2197), http://www.gazetapodatnika.pl/ artykuly/przedsiebiorstwa_spoleczne_doczekaja_ sie_wlasnej_ustawy-a_19862.htm (dostęp: 24.04.2017). Giza-Poleszczuk A., Hausner J. (2008). „Wprowadzenie - ekonomia społeczna i rozwój", (w:) A. Giza- odpowiednich warunków egzystencjalnych, polegających na tworzeniu przyjaznego środowiska (otoczenia), umożliwiającego wsparcie, jak i zapewniającego dalsze kierunki rozwoju PES-ów. Diagnoza sytuacji społeczno-gospodarczej województwa opolskiego wykazuje występowanie niekorzystnych zjawisk społecznych, takich jak wzrost zagrożenia wykluczeniem społecznym czy starzenie się społeczeństwa. Rozwiązaniem niwelującym niekorzystne zjawiska społeczne w województwie opolskim jest infrastruktura wsparcia ES wraz ze swoimi podmiotami, gdzie zgodnie z nowoczesnymi trendami w obszarze polityki społecznej promowane jest aktywne społeczeństwo (odejście od pomocy doraźnej na rzecz aktywizowania oraz znacznego usamodzielnienia się społecznego). Moim zdaniem obecny rozwój PES w województwie opolskim jest obciążony aktualną sytuacją społeczno-gospodarczą, co może hamować powstawanie nowych podmiotów i wskazywać na słabość instytucji wspierających jego rozwój.

-Poleszczuk, J. Hausner (red), Ekonomia społeczna w Polsce: osiagnięcia, bariery rozwoju i potencjał w świetle wyników badań (s. 11-40). Warszawa: FISE.

Herbst K. (2013). "Perspektywy ekonomii społecznej", Ekonomia społeczna, nr 1 (6), s. 9-19.

Kaźmierczak T. (2007). „Zrozumieć ekonomię społeczną", (w:) T. Kaźmierczak, M. Rymsza (red.), Kapitał społeczny. Ekonomia społeczna (s. 93-126). Warszawa: Instytut Spraw Publicznych.

Klimowicz M. (2008). „Ekonomia społeczna w Polsce jako element zwiększania spójności gospodarczo-społecznej. Integracja społeczności lokalnej w sferze gospodarczej", (w:) A. Wiktorska-Święcka (red.), Wyprowadzić na prosta. Innowacyjne metody aktywizacji społecznej i zawodowej na przykładzie wdrażania modelu lokalnej sieci wsparcia osób bezdomnych i zagrożonych bezdomnościa (s. 115-132). Wrocław: Wyd. Oficyna Wydawnicza ATUT.

Komisja Europejska (2010). Europa 2020 - Strategia na rzecz intelektualnego i zrównoważonego rozwoju sprzyjającego właczeniu społecznemu (COM 2010), Bruksela: Komisja Europejska, http://eur-lex.europa. eu/LexUriServ/LexUriServ.do?uri=COM:2010:2020:FIN:PL:PDF (dostęp: 24.04.2017). 
Komisja Europejska (2011). Inicjatywa na rzecz przedsiębiorczości społecznej. Budowanie ekosystemu sprzyjajacego przedsiębiorstwom społecznym w centrum społecznej gospodarki i społecznych innowacji. Bruksela: Komisja Europejska, http://eur-lex.europa. eu/LexUriServ/LexUriServ.do?uri=COM:2011:0682:FIN:PL:PDF (dostęp: 24.04.2017).

KPRES (2012). Krajowy Program Rozwoju Ekonomii Społecznej. Projekt: czerwiec. Zespół ds. rozwiązań systemowych w zakresie ekonomii społecznej. Warszawa, http://www.ekonomiaspoleczna.pl/files/ wiadomosci.ngo.pl/public/korespondenci/portal_ ekonomiaspoleczna/KPRES8.06.2012.pdf (dostęp: 24.04.2017).

Kwiatkowska M., Kucharska J., Wiesiołek A., Nawara T., Gawinek A., Kosmala T., Piechowicz D. (2011). Rozwój Ekonomii Społecznej na Opolszczyźnie. Opole: Opolskie Centrum Wspierania Inicjatyw Pozarządowych.

Mair J., Robinson J., Hockerts K. (2010). Współczesna polityka społeczna. Przedsiębiorczość społeczna. Warszawa: Elipsa.

Okraska R. (2012). Edward Abramowski. Braterstwo, solidarność, współdziałanie. Pisma spółdzielcze i stowarzyszeniowe. Łódź: Stowarzyszenie Obywatele - Obywatelom.

Projekt (2015). Projekt. Ustawa o przedsiębiorstwie społecznych i wspieraniu ekonomii społecznej, http://orka.sejm.gov.pl/druki7ka.nsf/projekty/7-020-1359-2015/\$file/7-020-1359-2015.pdf (dostęp 24.04.2017).

ROPS (2015). Wojewódzki Program Pomocy i Integracji Społecznej na lata 2016-2025. Opole: Regionalny
Ośrodek Polityki Społecznej w Opolu, http://rops-opole.pl/strategie_i_programy/Zal.\%20Nr\%201\%20 Program\%20pomocy\%20i\%20integracji\%20spolecznej\%202016-2025.pdf (dostęp 24.04.2017).

ROPS (2016). Opolski program rozwoju ekonomii społecznej na lata 2016-2022. Opole: Regionalny Ośrodek Polityki Społecznej w Opolu, http://rops-opole. pl/strategie_i_programy/Opolski\%20Program\%20 Rozwoju\%20Ekonomii\%20Spo\%C5\%82ecznej\%20 na\%20lata\%202016-2022_.pdf (dostęp 24.04.2017).

Ustawa z dnia 20 kwietnia 2004 r. o promocji zatrudnienia i instytucjach rynku pracy (Dz.U. 2004 nr 99 poz. 1001)

Ustawa z dnia 24 kwietnia 2003 r. o działalności pożytku publicznego i o wolontariacie (Dz.U. 2003 nr 96 poz. 873).

Ustawa z dnia 27 kwietnia 2006 r. o spółdzielniach socjalnych (Dz.U. 2006 nr 94 poz. 651).

Ustawa z dnia 27 sierpnia 1997 r. o rehabilitacji zawodowej i społecznej oraz zatrudnianiu osób niepełnosprawnych (Dz.U. 1997 nr 123 poz. 776).

Ustawa z dnia 6 kwietnia 1984 r. o fundacjach (Dz.U. 1984 nr 21 poz. 97).

Ustawa z dnia 7 kwietnia 1989 r. prawo o stowarzyszeniach (Dz.U. 1989 nr 20 poz. 104).

Wojciechowski S. (1939). Historia spółdzielczości polskiej do 1914 r. Warszawa: Spółdzielczy Instytut Naukowy.

Zarząd (2015). Wojewódzka strategia w zakresie polityki społecznej na lata 2016-2025. Opole: Zarząd Województwa Opolskiego, http://rops-opole.pl/ strategie_i_programy/STRATEGIA\%20POLITYKI\%20 SPOLECZNEEJ\%202016-2025.pdf (dostęp 24.04.2017).

\section{Development of social economy entities in Poland with particular emphasis on the Opole region: Institutional and organizational conditions}

Summary: The development of social economy entities (PES) in the Opole Voivodeship is mainly related to growing regional social needs. Limited financial resources in the sphere of social policy result in the lack of effective solutions in the area of social and economic problems. The aim of this article is to present the current state of PES development in the Opolskie Voivodship with respect to the time perspective 2009-2017. The changes in the number of social economy entities in Opolskie voivodship was also presented in order to show the significance of this indicator for public actions aimed at the development of institutional and organizational support. In the theoretical layer, literature analysis was used to examine the organizational conditions supporting the implementation of conditions conducive to the development of PES in the Opolskie Voivodeship. In the empirical layer, research methods of data analysis (quantitative), based on the analysis of the formation of new PES were used. These data will serve to better understand the conditions that favor and inhibit the development of PES in the Opolskie region. The author shows a disturbing tendency in the slowing growth of new PES.

Keywords: social economy, social policy, social enterprises. 


\section{Prawa autorskie i licencja / Copyright and License}

Artykuł opublikowano na licencji Creative Commons

Uznanie autorstwa - Użycie niekomercyjne - Bez utworów zależnych 3.0 Polska

http://creativecommons.org/licenses/by-nc-nd/3.0/pl/

This article is published under the terms of the Creative Commons

Attribution - NonCommercial - NoDerivs (CC BY-NC-ND 3.0) License

http://creativecommons.org/licenses/by-nc-nd/3.0/ 